\title{
KURANGNYA MINAT BELAJAR DARING SISWA DI SD INPRES SALUMADINGIN
}

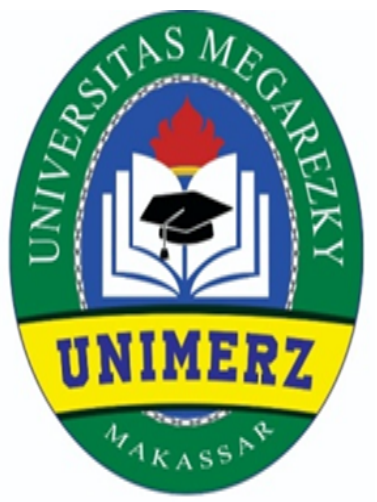

DISUSUN OLEH :

NAMA : MARJUNI. L

\section{PROGRAM STUDI SARJANA PENDIDIKAN GURU SEKOLAH DASAR}

FAKULTAS KEGURUAN DAN ILMU PENDIDIKAN

UNIVERSITAS MEGA REZKY

$2021 / 2022$ 


\section{KATA PENGANTAR}

Puji syukur kehadirat Tuhan Yang Maha Esa yang mana berkat Rahmat dan Hidayah-Nya sehingga kami dapat menyelesaikan makalah mata kuliah Kapita Selekta Pendidikan dengan judul " KURANGNYA MINAT BELAJAR DARING SISWA DI SD INPRES SALUMADINGIN "

Salawat serta salam tak lupa pula kami haturkan kepada Nabi Besar Muhammad SAW yang mana telah membawa dan menuntun Kami dari zaman kegelapan menuju zaman yang terang benderang ini. Terimakasih pula kami haturkan kepada semua pihak yang membantu dalam penyusunan makalah ini, terutama kepada dosen pengampu mata kuliah Manajemen Kelas dengan Dosen Pengampu Jumawati, S.Pd.,M.Pd Tanpa bantuan dan dukungan dari semua pihak maka makalah ini tidak dapat mencapai proses akhir penulisan.Kami menyadari bahwa makalah ini masih jauh dari sempurna, oleh karena itu kritik dan saran dari semua pihak yang bersifat membangun selalu kami harapkan demi kesempurnaan makalah ini.Akhir kata, kami sampaikan terima kasih kepada semua pihak yang telah berperan serta dalam penyusunan makalah ini dari awal sampai akhir. Semoga Allah SWT senantiasa meridhoi segala usaha kita semoga makalah tentang observasi masalah yang dilakukan guru dalam pembelajaran daring dan bimbingan yang dilakukan guru dalam mengatasi hal tersebut bisa memberi manfaat ataupun inspirasi pada pembaca.

Makassar, 23, juli, 2021

Penulis

MARJUNI. L I

DAFTAR ISI 
KATA PENGANTA.

Daftar Isi

Bab I PENDAHULUAN

A.Latar Belakang

B.Masalah atau Topik Bahasan

C.Tujuan Penelitian/Makalah

BAB II TEKS UTAMA

A.Metode Penelitian

B.Hasil dan Pembahasan

BABIII PENUTUP

A.Kesimpulan

B.Saran

Daftar Rujukan

Lampiran

BAB I 


\section{PENDAHULUAN}

\section{A. Latar belakang}

COVID-19 telah menjadi pademi, sehingga pemerintah di bebagai negara telah menerapkan lockdown atau karantina. Pengertian karantina menurut UU Republik Indonesia Nomor 6 tahun 2018 tentang Kekarantinaan Kesehatan adalah pembatasan kegiatan dan/atau pemisahan seseorang yang terpapar penyakit menular sebagaimana ditetapkan dalam peraturan perundang-undangan meskipun belum menunjukkan gejala apapun untuk mencegah kemungkinan penyebaran ke orang di sekitarnya (Ali, 2020).

Pemerintah Indonesia telah menghimbau warga untuk tetap di dalam rumah dan mengisolasi diri. Salah satunya Pemerintah Indonesia menerapkan aturan PSBB yang merupakan singkatan dari Pembatasan Sosial Berskala Besar yang dibuat dalam rangka penanganan COVID-19. Hal ini dilakukan dengan harapan virus tidak menyebar lebih luas dan upaya penyembuhan dapat berjalan maksimal. Dalam usaha pembatasan sosial ini pemerintah Indonesia juga telah membatasi kegiatan diluar rumah seperti kegiatan pendidikan yang telah dilakukan melalui pembelajaran online.

\section{B. Masalah/topik pembahasan}

Kurangnya Minat belajar siswa SD INPRES SALUMADINGIN di masa pandemi

C. Tujuan Penelitian

Adapun tujuan dari penelitian ini adalah untuk mengetahui faktor-faktor penghambat kurangnya minat belajar siswa di SD INPRES SALUMADINGIN dan penanggulangannya 
BAB II

PEMBAHASAN

\begin{abstract}
A. Hakikat Minat belajar siswa
Minat belajar siswa dalam mengikuti pembelajaran merupakan sesuatu yang penting dalam kelancaran proses belajar mengajar. Siswa yang mempunyai minat belajar tinggi dalam proses pembelajaran dapat menunjang proses belajar mengajar untuk semakin baik, begitupun sebaliknya minat belajar siswa yang rendah maka kualitas pembelajaran akan menurun dan akan berpengaruh pada hasil belajar. Slameto (1995: 57) menerangkan minat adalah "Kecenderungan hati yang tinggi terhadap sesuatu". Minat merupakan sifat yang relatif menetap pada diri seseorang. Minat adalah ketertarikan atau kecenderungan yang tetap untuk memperhatikan atau terlibat terhadap sesuatu hal karena menyadari pentingnya atau bernilainya hal tersebut.
\end{abstract}

B. Penyebab Menurunya Minat belajar siswa

Adapun faktor-faktor yang mengakibatkan kurangnya Minat belajar daring siswa di SD INPRES SALUMADINGIN dan cara Penanggulangannya

\title{
1. Media pembelajaran yang terbatas dan kurang menarik
}

Penggunaan media pembelajaran yang tidak menarik membuat siswa tidak menyukai pembelajaran hal menyebabkan minat belajar siswa rendah. Menurut Henry (2020) media pembelajaran yang menarik mempengaruhi minat belajar siswa. Untuk itu setiap guru dituntut untuk membuat media pembelajaran yang menarik. Dalam kondisi pembelajaran dari rumah guru harus ekstra belajar dan berusaha membuat pembelajaran semenarik mungkin.

Untuk mengatasi hal tersebut, setiap guru dilatih dan dituntut untuk belajar baik secara mandiri melalui youtube ataupun bertanya dengan teman yang lebih memahami tentang media-media interaktif yang dapat digunakan dalam pembelajaran.

\section{Jaringan Internet}

Kemudahan penggunaan aplikasi Whatsapp bagi kalangan guru dan walimurid, akan terhambat karena di jaringan di Salumadingin kurang mendukung murid/anak sekolah untuk mengikuti pembelajaran daring. Akibatnya materi pembelajaran yang diberikan oleh guru juga menjadi terhambat dan terlambat.

Solusinya yaitu siswa bisa belajar dengan teman dekat rumah dan guru sebaiknya menyiapkan media seperti modul dan di share agar siswa dapat belajar mandiri.

\section{Fasilitas Pembelajaran}

Dalam proses pembelajaran, pemanfaatan fasilitas belajar yang baik menentukan minat belajar dalam proses pembelajaran online. Pembelajaran online memerlukan fasilitas yang menunjang pembelajaran seperti internet, dan ditunjang dengan media teknologi seperti handphone, leptop, komputer dan lain-lain. Pemanfaatan fasilitas yang baik akan memaksimalkan materi yang akan di sampaikan.

Tapi lain halnya dengan siswa SD INPRES SALUMADINGIN lebih banyak menggunakan 
Hp dalam pembelajaran. Ada sebagian siswa juga yang memiliki Hp kurang memadai karena kualitas Hpnya belum sepenuhnya dapat mengakses ataupun mendownload vidio pembelajaran yang diberikan oleh guru.

Upaya untuk mengatasi hal tersebut yaitu dengan memberi bantuan kepada beberapa siswa yang tidak memiliki atau pun hannya memiliki $\mathrm{Hp}$ dengan kualitas rendah ataupun berkomunikasi dengan orangtua siswa agar menyuruh anaknya belajar melalui Hp saudara ataupun belajar bersama teman yang dekat dengan rumahnya.

\section{Kualitas pembelajaran}

Dalam proses pembelajaran online, guru merupakan faktor penentu keberhasilan pembelajaran online. Guru adalah foktor yang paling menonjol dalam penentuan. Banyak guru-guru lama SD INPRES SALUMADINGIN yang kurang memahami aplikasi-aplikasi baru dalam pembelajaran. Sehingga mereka tidak bisa menggunakan aplikasi-aplikasi tersebut dan hanya menggunakan WA grup yang membuat pembelajaran itu kurang menarik bagi siswa. Hal ini membuat kualitas pembelajaran yang kurang bagus.

Solusinya seharusnya diadakan pelatihan dan pembelajaran guru untuk mengembangkan kemampuan guru yang dapat dilakukan secara daring, sehingga guruguru dapat mengikuti dan menggunakan aplikasi-aplikasi modern yang dapat digunakan dalam pembelajaran agar dapat membuat pembelajaran lebih menarik.

\section{Orangtua}

Orangtua siswa di salumadingin berpendapat jika tugas sudah dikirmkan kepada guru, maka selesai kegiatan belajar pada hari itu. Hal ini mengakibatkan terjadinya komunikasi searah, tanpa adanya pengawasan dalam belajar, padahal dengan orangtua mendampingi anak dalam proses belajar, anak akan lebih semangat dengan materi yang dipelajarinya. Serta siswa akan lebih tenang ketika ia harus mempelajari materi yang di sampaikan oleh guru. Orangtua juga harus memberikan kesempatan kepada anaknya untuk mendapatkan hasil belajar yang baik dengan cara menyediakan suasana belajar yang menyenangkan, kreatif dan kondusif sesuai dengan keinginan anak, agar minat belajarnya semakin tinggi serta mudah memahami materi pembelajaran yang di sampaikan oleh guru.

Untuk mengatasinya maka perlunya dilakukan konsultasi antara walikelas dengan orangtua siswa agar kondisi belajar siswa tetap dalam pengawasan orang tuanya. Hal ini sesuai dengan pendapat Henry (2020) bahwa dengan bantuan pengawasan orangtua dengan baik maka siswa dapat mengikuti pelajaran dan termotivasi dalam belajar.

Adapun cara agar siswa rajin belajar yaitu memberikan motivasi. Adapun pengertian motivasi menurut Jusmawati yaitu:

\section{Pengertian motivasi}

Menurut Jusmawati, Motivasi belajar adalah faktor psikis yang bersifat non intelektual. Peranannya yang khas adalah dalam hal penumbuhan gairah, merasa senang dan semangat untuk belajar. siswa yang memiliki motivasi kuat, akan mempunyai banyak energi untuk melakukan kegiatan belajar. ibaratnya seseorang itu menghadiri suatu ceramah, tetapi ia tidak tertarik pada materi yang diceramahkan, maka tidak akan mencamkan, apalagi mencatat isi ceramah tersebut. Seseorang tidak memiliki motivasi, kecuali karena paksaan atau sekedar seremonial. Seorang siswa yang memiliki intelegensia cukup tinggi, mentak (boleh jadi) gagal karena kekurangan motivasi. Hasil belajar akan optimal kalau ada motivasi yang tepat. Bergayut dengan ini maka kegagalan 
belajar siswa jangan begitu saja mempersalahkan pihak siswa, sebab mungkin saja guru tidak berhasil dalam memberi motivasi yang mampu membangkitkan semangat dan kegiatan siswa untuk berbuat/belajar. jadi tugas guru bagaimana mendorong para siswa agar pada dirinya tumbuh motivasi.7

\section{Peranan Motivasi dalam Belajar dan Pembelajaran}

- Peran motivasi dalam menentukan penguatan belajar Motivasi dapat berperan dalam penguatan belajar apabila seorang anak yang belajar dihadapkan pada suatu masalah yang memerlukan pemecahan, dan hanya dapat dipecahkan berkat bantuan hal-hal yang pernah dilaluinya.

- Peran motivasi dalam memperjelas tujuan belajar Peran motivasi dalam memperjelas tujuan belajar erat kaitannya dengan kemaknaan belajar.

- Motivasi menentukan ketekunan belajar Seorang anak yang telah termotivasi untuk belajar sesuatu, akan berusaha mempelajarinya dengan baik dan tekun, dengan harapan memperoleh hasil yang baik.

3. Prinsip-Prinsip Motivasi Belajar

Berdasarkan hasil penelitian yang saksama tentang upaya yang mendorong motivasi belajar siswa. Khususnya pada sekolah yang menganut pandangan demokrasi pendidikan dan yang mengacuh pada pengembangan self motivation keenneth $\mathrm{H}$. Hooveer, mengemukakan prinsip-prinsip motivasi belajar sebagai belajar, sebagai berikut:

- Pujian lebih efektif dari pada hukuman.

- Para siswa mempunyai kebutuhan psikologis (yang bersifat dasar) yang perlu mendapat kepuasan.

- Motivasi yang bersumber dari dalam diri individu lebih efektif dari pada motivasi yang berasal dari luar.

- Tingkah laku (perbuatan) yang serasi (sesuai dengan keinginan) perlu dilakukan penguatan (reinforcement).

- Motivasi mudah menjalar kepada orang lain.

- Pemahaman yang jelas terhadap tujuan-yujuan akan merangsang motivasi belajar.

- Tugas-tugas yang dibebakan oleh diri sendiri akan menimbulkan minat yang lebih besar untuk melaksanakannya dari pada tugas-tugas yang dipaksakan dari luar.

- Ganjaran yang berasal dari luar kadang-kadang diperlukan dan cukup efekti untuk merangsang minat belajar.

- Teknik dan prosedur pembelajaran yang bervariasi adalah efektif untuk memelihara minat siswa.

- Minat khusus yang dimiliki oleh siswa bermanfaat dalam belajar dan pembelajaran.

- Kegiatan-kegiatan yang dilakukan untuk merangsang minat belajar bagi siswa yang lamban, ternayata tidak bermakna bagi siswa yang tergolong pandai, karena adanya perbedaan tingkat kemampuan.

- Kecemasan dan frustasi yang lemah kadang-kadang dapat membantu siswa belajar menjadi lebih baik. 
- Kecemasan yang serius akan menyebabkan kesulitan belajar dan mengganggu perbuatan belajar siswa, karena perhatiannya akan terarah pada hal lain.

- Tugas-tugas yang terlampau tulis dikerjakan dapat menyebabkan prustasi pada siswa, bahkan dapat mengakibatkan demoralisasi dalam belajar, yakni perbuatan yang tidak wajar (misal: mencontohkan).

- Masing-masing siswa memiliki kadar emosi yang berbeda satu dengan yang lainnya.

- Pengaruh kelompok umumnya lebih efektif dalam motivasi belajar dibandingkan dengan paksaan orang dewasa.

- Motivasi yang kuat lebih erat hubungannya dengan kreativitas.

\section{Cara Menggerakkan Motivasi Belajar Siswa}

Guru dapat menggunakan berbagai cara untuk menggerakkan atau membangkitkan otivasi belajar siswanya, ialah sebagai berikut:
a. Memberi angka.
b. Pujian.
c. Hadiah.
d. Kerja kelompok.
e. Persaingan.
f. Tujuan dan level of aspiratio.
g. Sarkasme.
h. Penilaian.
i. Karya wisata dan ekskursi.
j. Film pendidikan.
k. Belajar melalui radio

Motivasi mempengaruhi tingkat keberhasilan atau kegagalan belajar, dan pada umumnya belajar tanpa motivasi akan sulit untuk berhasil. Oleh sebab itu pembelajaran harus disesuaikan dengan kebutuhan, dorongan, motif, minat yang dimiliki oleh peserta didik. Penggunaan motivasi dalam mengajar bukan hanya melengkapi elemen pembelajaran, tetapi juga menjadi faktor yang menentukan pembelajaran yang efektif. Memotivasi bukan sekedar mendorong atau memerintahkan seseorang untuk melakukan sesuatu, melainkan sebuah seni yang melibatkan beberapa kemampuan dalam mengenali dan mengelola emosi diri sendiri dan orang lain. 


\section{BAB III}

\section{PENUTUP}

\section{A. KESIMPULAN}

Sesuai dengan data yang diperoleh dari penelitian, terdapat 5 faktor yang menghambat minat belajar siswa di SD INPRES SALUMADINGIN yaitu (1) media pembelajaran yang digunakan kurang menarik, solusi yang diberikan dengan memberikan pelatihan kepada guru atau belajar melalui youtube, (2) jaringan internet baik guru maupun siswa kurang mendudkung, Solusinya yaitu siswa bisa belajar dengan teman dekat rumah dan guru sebaiknya menyiapkan media seperti modul dan di share agar siswa dapat belajar mandiri, (3) fasilitas pembelajaran seperti Hp yang dimiliki, solusinya dengan pihak sekolah memberikan bantuan kepada siswa yang tidak memiliki $\mathrm{Hp}$ ataupun menyuruh siswanya belajar dengan teman terdekat rumah yang memiliki $\mathrm{Hp}$, (4) kualitas pembelajaran, solusinya dengan mengadakan

pelatihan-pelatihan guru secara online untuk meningkatkan mutu guru dan kualitas pembelajaran, (5) orangtua, solusinya dengan melakukan diskusi dengan orangtua agar orangtua turut membantu anaknya dalam belajar karena siswa sekolah dasar sangat membutuhkan bantuan dan pengawasan orang tua.

\section{B. SARAN}

Demikian makalah yang penulis susun, kiranya banyak kekurangan dan kesalahan baik dalam penyusunan kalimat atau yang lainnya. Semoga dengan adanya ketidak sempurnaan itu menjadikan referensi bagi langkah kedepan. Semoga makalah ini dapat bermanfaat bagi kita semua. 


\section{DAFTAR PUSTAKA}

Hasil observasi di SD INPRES SALUMADINGIN

Jusmawati-2019-repository.iaimsinjai 